ISSN 1678-3921

Journal homepage: www.embrapa.br/pab

For manuscript submission and journal contents, access: www.scielo.br/pab

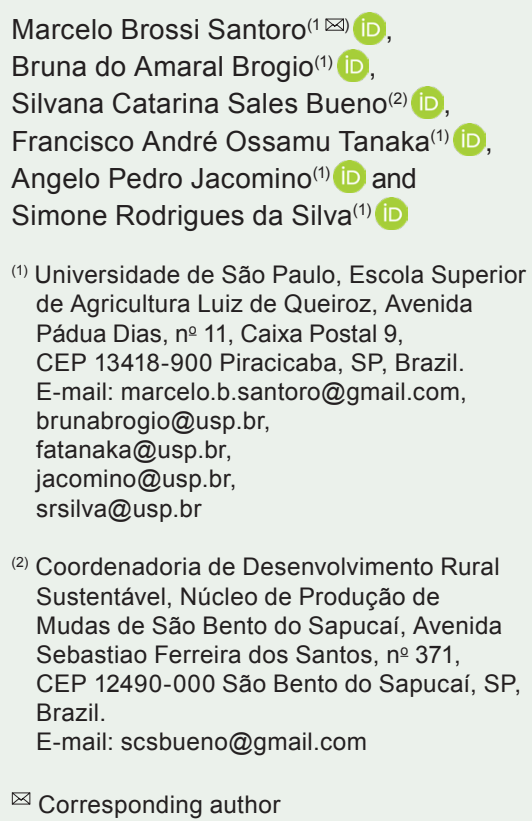

(2) Coordenadoria de Desenvolvimento Rural Sustentável, Núcleo de Produção de Mudas de São Bento do Sapucaí, Avenida Sebastiao Ferreira dos Santos, № 371, CEP 12490-000 São Bento do Sapucaí, SP, Brazil.

E-mail: scsbueno@gmail.com

$\bowtie$ Corresponding author

Received

January 21, 2021

Accepted

May 18, 2021

How to cite

SANTORO, M.B.; BROGIO, B. do A.;

BUENO, S.C.S.; TANAKA, F.A.O.;

JACOMINO, A.P.; SILVA, S.R. da. Vegetative propagation of Campomanesia phaea by the air-layering and grafting techniques. Pesquisa Agropecuária Brasileira, v.56, e02402, 2021. DOI: https://doi.org/10.1590/S1678-3921. pab2021.v56.02402.

\section{Vegetative propagation of Campomanesia phaea by the air- layering and grafting techniques}

\begin{abstract}
The objective of this work was to evaluate the air-layering and grafting techniques in the production of cambuci (Campomanesia phaea) plants. Two experiments were conducted in randomized complete blocks for air-layering, using adult cambuci plants, and two completely randomized for the grafting, using seedlings. Air layering was evaluated with different rates of indolebutyric acid; the splice, side-veneer, and chip-budding techniques were used for grafting. Air-layering rooting was not favored by the application of indolebutyric acid rates, whereas side-veneer grafts ensured the fixation of $6 \%$ of the grafts. Histological analyses of the air layers revealed the action of parenchyma cells from the xylem in the formation of structures similar to calluses. In the grafted plants, these cells ensured tissue union and regeneration. The air-layering technique was unfeasible, but grafting is recommended to establish cambuci tree genotypes.
\end{abstract}

Index terms: air layer, cambuci tree, histological analyses, indolebutyric acid, scion.

\section{Propagação vegetativa de Campomanesia phaea pelas técnicas de alporquia e enxertia}

Resumo - O objetivo deste trabalho foi avaliar as técnicas de alporquia e enxertia na produção de plantas de cambucizeiro (Campomanesia phaea). Foram conduzidos dois experimentos em blocos ao acaso para alporquia, com plantas adultas de cambuci, e dois inteiramente casualizados para a enxertia, utilizando mudas. A alporquia foi avaliada com diferentes doses de ácido indolbutírico, e as técnicas do tipo inglês simples e fenda lateral foram utilizadas para a enxertia. $\mathrm{O}$ enraizamento dos alporques não foi favorecido pela aplicação de doses de ácido indolbutírico, enquanto a enxertia do tipo fenda lateral garantiu a fixação de $6 \%$ dos enxertos. Análises histológicas dos alporques revelaram atividade das células parenquimáticas do xilema na formação de estruturas similares a calos. Nas plantas enxertadas, essas células garantiram a união e a regeneração dos tecidos. A técnica da alporquia foi inviável, mas a enxertia é recomendada para fixação de genótipos de cambucizeiro.

Termos para indexação: alporque, cambucizeiro, análise histológica, ácido indolbutírico, enxerto.

\section{Introduction}

The cambuci [Campomanesia phaea (O.Berg) Landrum] tree, native to the Atlantic Forest biome, belongs to the Myrtaceae family and occurs frequently in Southeastern Brazil (Lorenzi, 2014). Its fruits 
exhibit interesting organoleptic characteristics, such as high fiber and vitamin $\mathrm{C}$ contents, displaying a significant nutritional value (Bianchini et al., 2016; Tokairin et al., 2018).

The main reproduction mode of this species is sexual multiplication through seeds, resulting in genetic offspring variability (Tokairin et al., 2018). However, vegetative propagation techniques such as cutting, layering, and grafting allow for the production of plants identical to their matrices (Davies Jr. et al., 2018). Layering is an alternative for species with difficulties regarding root grafting, as rooting occurs when the propagules are connected to the stock plant (Davies Jr. et al., 2018). Differently from this technique, grafting does not depend on the adventitious rooting process, but on the healing, regeneration, and union of the graft and rootstock tissues, which then develop as a single plant (Fachinello et al., 2005).

Histological analyses aid in understanding the processes involved in these and other propagation techniques, identifying possible interfering factors to their successful adoption (Ribeiro et al., 2015). Although propagation assessments have been reported for other species belonging to the Myrtaceae family (Franzon et al., 2010; Lattuada et al., 2010; Cassol et al., 2015, 2017; Hossel et al., 2017), there are no known reports in the literature of histological analyses for cambuci plants obtained by vegetative propagation.

The objective of this work was to evaluate the airlayering and grafting techniques in the production of cambuci plants.

\section{Materials and Methods}

The air-layering experiment was carried out in the spring periods from mid-September to early December of 2017 and 2018, using adult cambuci trees - planted in 2006 in a $5 \times 4 \mathrm{~m}$ spacing -, belonging to the seedling production center of the experimental area of Coordenadoria de Desenvolvimento Rural Sustentável, located in the municipality of São Bento do Sapucaí, in the state of São Paulo, Brazil (22 $40^{\prime} 48.8^{\prime \prime S}$, $45^{\circ} 44^{\prime} 47.6^{\prime \prime} \mathrm{W}$, at an altitude of $880 \mathrm{~m}$ ). This area is characterized by a humid mesothermal climate, of the Cfb type, without a defined dry season (Alvares et al., 2013). Considering that cambuci tree flowering ensues from spring to early summer (Cordeiro et al., 2017), the experiment was conducted with plants exhibiting a low flower occurrence.

The air-layering procedures were carried out after the selection and identification of five branches, approximately $2 \mathrm{~cm}$ in diameter, from ten healthy and vigorous stock plants. The branches were girded at approximately $3 \mathrm{~cm}$ in length, by removing the superficial bark portion. Lanolin paste containing different rates of the indolebutyric acid (IBA) plant growth regulator $(0,1.500,3.000,4.500$, and 6.000 $\mathrm{mg} \cdot \mathrm{kg}^{-1}$ ) was applied to the exposed regions, which were covered with the Golden Mix coconut fiber substrate (Amafibra Ltda, Artur Nogueira, SP, Brazil) and with transparent plastic, tied together with a string (Davies Jr. et al., 2018). The layers were observed every month as to humidity, and, if necessary, water was added using a plastic syringe.

The experimental design was randomized complete blocks, comprising five treatments consisting of different IBA rates distributed in ten blocks of one plant each, totaling 50 layers. After 150 days, the plants were evaluated as to the number of live and rooted individuals or to callus-forming layers. The data were subjected to the analysis of variance (ANOVA), and treatments were compared by Tukey's means comparison test $(\mathrm{p}<0.05)$ using the SAS, version 9.4, statistical software (SAS Institute Inc., Cary, NC, USA).

The grafting techniques were carried out in the summer of 2017 and spring of 2018, in the experimental area belonging to the Department of Plant Production of Escola Superior de Agricultura Luiz de Queiroz of Universidade de São Paulo, located in the municipality of Piracicaba, in the state of São Paulo, Brazil (234' $29^{\prime}$ 'S, $47^{\circ} 37^{\prime} 45^{\prime \prime} \mathrm{W}$, at an altitude of $546 \mathrm{~m}$ ). The area presents a tropical humid climate, of the Cwa type, with dry winters and hot summers (Alvares et al., 2013). During both seasons, the cambuci trees developed from seeds and used as rootstocks were obtained from Coordenadoria de Desenvolvimento Rural Sustentável.

The experimental design adopted for both grafting seasons was completely randomized, comprising two treatments (splice-grafting and chip-budding in the summer trial and splice grafting and side-veneer in the spring) and ten replicates of five plants, totaling 100 grafts per experiment. The grafts for the summer trial were collected from semi-woody branches of 
the eight-year-old cambuci stock plant, located in the experimental area of Escola Superior de Agricultura Luiz de Queiroz. Regarding the spring trial, the grafts were collected from semi-woody branches obtained from a plant belonging to the collection of the seedling production center of Coordenadoria de Desenvolvimento Rural Sustentável (access number 7273). In order to avoid graft dehydration during transport to the experimental area, the collected grafts were wrapped in moistened paper, placed in plastic bags, and kept in thermal boxes. After the arrival at the experimental area, the bags were stored in a cold chamber at $15^{\circ} \mathrm{C}$ and $95 \%$ relative humidity until grafting.

After the grafting techniques were performed, the seedlings were maintained in a screened nursery (50\% shading) and manually irrigated as needed. During the 90-day experimental period, the seedlings were evaluated each month as to number of live grafts, number of shoots per graft (for the splice and side-veneer techniques), and length of the longest shoot. The data were subjected to the ANOVA, and treatments were compared by the Kruskal-Wallis nonparametric means comparison test $(\mathrm{p}<0.05)$ using the SAS, version 9.4, statistical software (SAS Institute Inc., Cary, NC, USA).

In order to assess the histological changes resulting from the layering and grafting procedures, layered samples with visible healing and the grafting region of surviving plants were collected, fixed in Karnovsky's solution (2.5\% glutaraldehyde, 4\% PFA, and $0.1 \mathrm{~mol} \mathrm{~L}^{-1}$ sodium cacodylate), dehydrated in an increasing ethyl alcohol scale $(30,50,70,90,100,100$, and $100 \%$ ), infiltrated in resin ethanol solution (1: 1 , $\mathrm{v} / \mathrm{v}$ ) for 48 hours and in pure historesin for 72 hours, and, finally, polymerized to form blocks (O'Brien et al., 1964). The polymerized blocks were then crosssectioned into $5 \mu \mathrm{m}$ thick cuts, using the Spencer 820 rotary microtome (American Optical Corporation, Scientific Instrument Division, Buffalo, NY, USA), placed on slides, and subjected to differential staining with toluidine blue $(0.05 \% \mathrm{w} / \mathrm{v}$; $\mathrm{pH} 3.2)$ (O'Brien et al., 1964).

After staining, the cuts were prepared with Entellan mounting medium between coverslips. The images were recorded using a digital camera and then computer connected to the Axio Imager light microscope (Carl Zeiss Microscopy, LLC, White Plains, NY, USA) with the aid of the Image-Pro Plus, version 6.3, software (Media Cybernetics, Inc., Rockville, MD, USA).

\section{Results and Discussion}

Regardless of the applied IBA rates, root formation was not observed in any air layer during both study years, only the healing of the annular region. The histological sections of the layered healing regions indicate the formation of groups of cells similar to a callus (Figure $1 \mathrm{~A}$ ), originating from the xylem

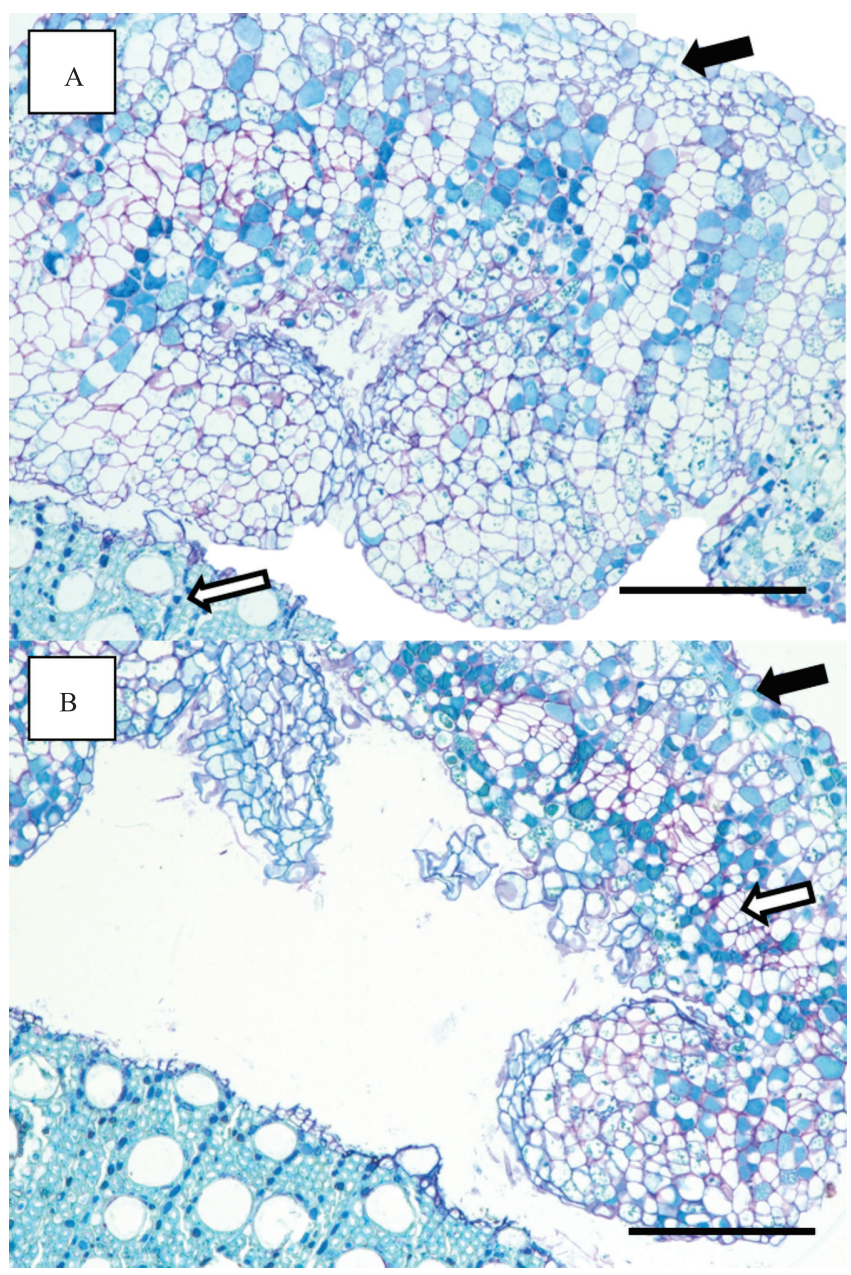

Figure 1. Cross-section of the ringed region of a healing cambuci (Campomanesia phaea) plant stem, showing the xylem cells of the branch in which layering was performed (empty arrow) and irregular and non-specialized parenchyma cells in the healing location (full arrow) (A); and deepening of the cross-section of the annular region of the healing cambuci plant stem with active periclinal division (empty arrow) and parenchyma cells (full arrow) (B). Scale bar $=200 \mu \mathrm{m}$. 
parenchyma cells. The multiplication of these cells (Figure $1 \mathrm{~B}$ ) led to the regeneration of bark tissues and not to tissue differentiation for root formation, resulting only in the healing of the injured region.

Other species, such as the guabiju [Myrcianthes pungens (O.Berg) D.Legrand] and gabiroba (Campomanesia xanthocarpa O.Berg) trees, also did not show root formation with the air layering technique (Hossel et al., 2017; Teleginski et al., 2018). However, positive results have been reported for some fruit species belonging to the Myrtaceae family, as the Plinia trunciflora (O.Berg) Kausel and Plinia cauliflora (Mart.) Kausel (Danner et al., 2006; Sasso et al., 2010) jabuticaba trees, with over $80 \%$ of rooted layering.

Although the literature mentions the benefits of applying plant growth regulators, such as IBA, to layering rooting (Davies Jr. et al., 2018), the results differ as to the best rate (Danner et al., 2006) and to rooting effects (Hossel et al., 2016). For jabuticaba trees, for example, the layering technique performed at the same time of the year and under the influence of IBA application has shown both positive (up to $100 \%$ rooting) and negative (no rooting) results (Cassol et al., 2015; Danner et al., 2006; Sasso et al., 2010). Unfortunately, the non-rooting of the layers observed in the present study did not allow for assessments on the effects of IBA applications.

Santos et al. (2016) found a great variability among cambuci trees from different populations, showing the low level of domestication of this species. Moreover, this variability, associated with a wide range of other factors, contributed to the failure of this method in the present work, indicating the importance of further research to guarantee the success of techniques for the propagation of native Brazilian species (Martins et al., 2015).

Regarding summer grafting, the splice-grafting and chip-budding techniques did not result in healing, and all grafts died in 30 days, making it impossible to evaluate the proposed variables.

However, spring grafting showed positive results, but with no significant differences between the sideveneer and splice-grafting techniques for the assessed variables. At the end of the experimental period, only $6 \%$ of the side-veneer grafts remained alive ( $\mathrm{p}$-value $=$ 0.0652 ), with an average of 0.3 shoots per graft ( $p$-value
$=0.0679)$ and of $3.6 \mathrm{~cm}$ in length for the longest shoot ( $\mathrm{p}$-value $=0.0682$.

The formation of the parenchyma tissue was observed in the grafting region of the surviving plants, ensuring tissue union and the joint formation of secondary tissues from the cambium (Figure 2). During this process, graft success can be explained by the continuity of the cell division and multiplication processes, guaranteeing tissue regeneration.

Graft death can occur due to several factors, such as incompatibility between tissues, environmental conditions during and after grafting, graft polarity, tissue health, grafting skills, and post-grafting techniques (Fachinello et al., 2005). The difficulty in tissue healing after the grafting of species belonging to the Myrtaceae family has been attributed to the presence of phenolic compounds and to the high level of lignification of the grafts and rootstocks (Fachinello et al., 2005; Silva et al., 2019).

For other species of the Myrtaceae family, grafting fixation is quite diverse, being of 40 to $60 \%$ for pitanga (Eugenia uniflora L.), 50\% for camu-camu [Myrciaria dubia (Kunth) McVaugh], and 20 to $61 \%$ for jabuticaba (Plinia spp.) plants (Suguino et al., 2003; Franzon et al., 2010; Lattuada et al., 2010; Malagi et al., 2012; Sasso et al., 2010; Cassol et al., 2017).

Although the graft fixation values reported by these same authors are considered low for commercial seedling production $(<50 \%)$, they are much higher than

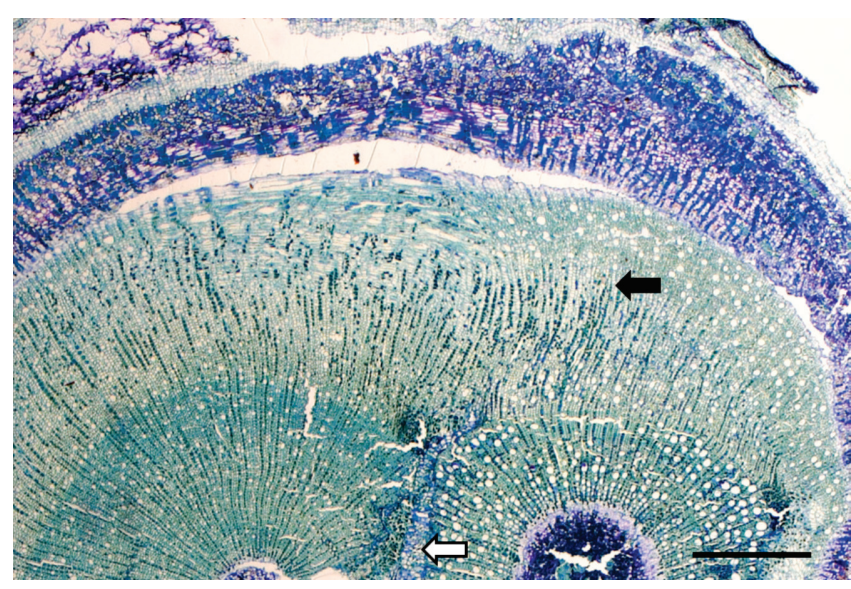

Figure 2. Cross-section of the cambuci (Campomanesia phaea) plant graft region in a side-veneer graft. Empty arrow, parenchymal tissue of the grafts; and full arrow, secondary tissues from the joint growth of the vascular exchange. Scale bar $=500 \mu \mathrm{m}$. 
that of $6 \%$ observed for cambuci plants in the present study when using the same grafting technique.

This low graft fixation cannot only be associated with the applied grafting techniques, since the failure of these methods is correlated to several other factors, such as tissue lignification degree, existing genetic variability, and even scarcity of information regarding the physiology and performance of the assessed species, which, in the case of the present work, is native and still in the early stages of the domestication process, where human action begins to act alongside natural selection. Therefore, despite the obtained results, grafting can still be considered an interesting alternative for fixing and/or rescuing genetic materials, leading to good fruit production and quality.

\section{Conclusions}

1. It is unviable to use the air-layering technique for the vegetative propagation of cambuci (Campomanesia phaea) plants during spring.

2. The side-veneer grafting technique performed in summer can be used to establish genetic materials, but not for commercial cambuci seedling production.

\section{Acknowledgments}

To Coordenação de Aperfeiçoamento de Pessoal de Nível Superior (Capes), for financing, in part, this study (Finance Code 001); to Conselho Nacional de Desenvolvimento Científico e Tecnológico (CNPq) and to Fundação de Amparo à Pesquisa do Estado de São Paulo (Fapesp, process number 2014/126063), for financial support; to Núcleo de Produção de Mudas de São Bento do Sapucaí of Coordenadoria de Desenvolvimento Rural Sustentável, (CDRS), for the plant material used to carry out the layering and grafting procedures; to Prof. Mario Tomazello Filho, for the used laboratory and equipment; to Edilson Giacon, a nursery- and plantsman, for teachings; and to Eder de Araujo Cintra, for performing the grafting techniques.

\section{References}

ALVARES, C.A.; STAPE, J.L.; SENTELHAS, P.C.; GONÇALVES, J.L. de M.; SPAROVEK, G. Köppen's climate classification map for Brazil. Meteorologische Zeitschrift, v.22, p.711-728, 2013. DOI: https://doi.org/10.1127/0941-2948/2013/0507.
BIANCHINI, F.G.; BALBI, R.V.; PIO, R.; SILVA, D.F. da; PASQUAL, M.; VILAS BOAS, E.V. de B. Caracterização morfológica e química de frutos de cambucizeiro. Bragantia, v.75, p.10-18, 2016. DOI: https://doi.org/10.1590/1678-4499.096.

CASSOL, D.A.; PIROLA, K.; DOTTO, M.; CITADIN, I.; MAZARO, S.M.; WAGNER JÚNIOR, A. Grafting technique and rootstock species for the propagation of Plinia cauliflora. Ciência Rural, v.47, e20140452, 2017. DOI: https://doi.org/10.1590/0103-8478cr20140452.

CASSOL, D.A.; WAGNER JÚNIOR, A.; PIROLA, K.; DOTTO, M.; CITADIN, I. Embalagem, época e ácido indolbutírico na propagação de jabuticabeira por alporquia. Revista Brasileira de Fruticultura, v.37, p.267-272, 2015. DOI: https://doi.org/10.1590/0100-2945-011/14.

CORDEIRO, G.D.; PINHEIRO, M.; DÖTTERL, S.; ALVESDOS-SANTOS, I. Pollination of Campomanesia phaea (Myrtaceae) by night-active bees: a new nocturnal pollination system mediated by floral scent. Plant Biology, v.19, p.132-139, 2017. DOI: https://doi.org/10.1111/plb.12520.

DANNER, M.A.; CITADIN, I.; FERNANDES JUNIOR, A. de A.; ASSMANN, A.P.; MAZARO, S.M.; DONAZZOLO, J.; SASSO, S.A.Z. Enraizamento de jabuticabeira (Plinia trunciflora) por mergulhia aérea. Revista Brasileira de Fruticultura, v.28, p.530-532, 2006. DOI: https://doi.org/10.1590/ S0100-29452006000300043.

DAVIES JR., F.T.; GENEVE, R.L.; WILSON, S.B. Hartmann \& Kester's plant propagation: principles and practices. $9^{\text {th }}$ ed. New York: Pearson, 2018. 880p.

FACHINELLO, J.C.; HOFFMANN, A.; NACHTIGAL, J.C. (Ed.). Propagação de plantas frutíferas. Brasília: Embrapa Informação Tecnológica; Bento Gonçalves: Embrapa Uva e Vinho, 2005. 221p.

FRANZON, R.C.; GONÇALVES, R. da S.; ANTUNES, L.E.C.; RASEIRA, M. do C.B. Propagação vegetativa de genótipos de pitangueira (Eugenia uniflora L.) do Sul do Brasil por enxertia de garfagem. Revista Brasileira de Fruticultura, v.32, p.262-267, 2010. DOI: https://doi.org/10.1590/S0100-29452010005000003.

HOSSEL, C.; HOSSEL, J.S.A. de O.; WAGNER JÚNIOR, A.; RADAELLI, J.C.; ALEGRETTI, A.L. Propagação de jamboleiro por alporquia. Brazilian Journal of Applied Technology for Agricultural Science, v.9, p.97-102, 2016.

HOSSEL, C.; WAGNER JÚNIOR, A.; HOSSEL, J.S.A. de O.; FABIANE, K.C.; CITADIN, I. 'Cerejeira da mata' and 'guabijuzeiro' propagation by air layering. Comunicata Scientiae, v.8, p.581-586, 2017. DOI: https://doi.org/10.14295/CS.v8i4.2194.

LATTUADA, D.S.; SOUZA, P.V.D. de; GONZATTO, M.P. Enxertia herbácea em Myrtaceae nativas do Rio Grande do Sul. Revista Brasileira de Fruticultura, v.32, p.1285-1288, 2010. DOI: https://doi.org/10.1590/S0100-29452010005000115.

LORENZI, H. Árvores brasileiras: manual de identificação e cultivo de plantas arbóreas nativas do Brasil. 6.ed. Nova Odessa: Instituto Plantarum, 2014. 379p.

MALAGI, G.; CITADIN, I.; SCARIOTTO, S.; WAGNER JÚNIOR, A.; SACHET, M.R. Enxertia interespecífica de jabuticabeira: influência do tipo de garfo. Ciência Rural, 
v.42, p.221-224, 2012. DOI: https://doi.org/10.1590/S010384782012005000006 .

MARTINS, W.A.; MANTELLI, M.; SANTOS, S.C.; NETTO, A.P.C.; PINTO, F. Estaquia e concentração de reguladores vegetais no enraizamento de Campomanesia adamantium. Revista de Ciências Agrárias, v.38, p.58-64, 2015. DOI: https://doi.org/10.19084/rca.16869.

O'BRIEN, T.P.; FEDER, N.; MCCULLY, M.E. Polychromatic staining of plant cell walls by toluidine blue O. Protoplasma, v.59, p.368-373, 1964. DOI: https://doi.org/10.1007/BF01248568.

RIBEIRO, L.M.; NERY, L.A.; VIEIRA, L.M.; MERCADANTESIMÕES, M.O. Histological study of micrografting in passionfruit. Plant Cell, Tissue and Organ Culture, v.123, p.173-181, 2015. DOI: https://doi.org/10.1007/s11240-015-0824-1.

SANTOS, D.N.; NUNES, C.F.; SETOTAW, T.A.; PIO, R.; PASQUAL, M.; CANÇADO, G.M.A. Molecular characterization and population structure study of cambuci: strategy for conservation and genetic improvement. Genetics and Molecular Research, v.15, gmr15049134, 2016. DOI: https://doi.org/10.4238/gmr15049134.

SASSO, S.A.Z.; CITADIN, I.; DANNER, M.A. Propagação de jabuticabeira por enxertia e alporquia. Revista Brasileira de Fruticultura, v.32, p.571-576, 2010. DOI: https://doi.org/10.1590/S0100-29452010005000055.

SILVA, J.A.A. da; TEIXEIRA, G.H. de A.; CITADIN, I.; WAGNER JÚNIOR, A.; DANNER, M.A.; MARTINS, A.B.G. Advances in the propagation of Brazilian cherry tree. Revista Brasileira de Fruticultura, v.41, e-971, 2019. DOI: https://doi.org/10.1590/0100-29452019971.

SUGUINO, E.; APPEZZATO-DA-GLÓRIA, B.; ARAÚJO, P.S.R. de; SIMÃO, S. Propagação vegetativa de camu-camu por meio de enxertia intergenérica na família Myrtaceae. Pesquisa Agropecuária Brasileira, v.38, p.1477-1482, 2003. DOI: https://doi.org/10.1590/S0100-204X2003001200015.

TELEGINSKI, F.; ZUFFELLATO-RIBAS, K.C.; KOEHLER, H.S.; DEGENHARDT-GOLDBACH， J.; TELEGINSKI， E. Resgate vegetativo de Campomanesia xanthocarpa Mart. ex O. Berg por alporquia. Ciência Florestal, v.28, p.820-826, 2018. DOI: https://doi.org/10.5902/1980509832100.

TOKAIRIN, T. de O.; SILVA, A.P.G. da; SPRICIGO, P.C.; ALENCAR, S.M. de; JACOMINO, A.P. Cambuci: a native fruit from the Brazilian Atlantic forest showed nutraceutical characteristics. Revista Brasileira de Fruticultura, v.40, e-666, 2018. DOI: https://doi.org/10.1590/0100-29452018666. 